\title{
Application of Flipped Classroom on the Sports Dance Teaching in Colleges and Universities-- Taking Routine Creation as an Example
}

\author{
Yonghua $\mathrm{Li}^{*}$ \\ Department of Physical Education, Northwest Agriculture and Forestry University, Yangling 7712100, Shaanxi, China
}

\begin{abstract}
Originated from America, the student-oriented flipped classroom, which focuses on the individual demands and expressions of students, has become a hot topic in education fields in and out of China, along with the development of information technology and updating of teaching ideas. This study attempts to establish a "task driven and ability targeted" flipped classroom mode, with the creation of sports dance class as the breakthrough point. The experimental results show that the model can effectively stimulate learners' interest in learning, cultivate students' autonomous learning awareness, improve the ability of creating dance, enable learners to obtain learning achievement experience from the flipped classroom, and thus cast reverse driving effect on autonomous learning.
\end{abstract}

Keywords: Colleges and universities, Creation, Flipped classroom, Sports dance, Teaching.

\section{INTRODUCTION}

With the development of information technology, webbased learning resources are being evolved, which lead to the trend that combines web-based learning and traditional classroom learning. The flipped classroom in which students learn new knowledge through online videos, to digest and consolidate to a comprehensive understanding, has born at the right moment and become popular gradually around the world, with the favor of the educators due to its unique charm. In recent years, Chinese scholars have done related researches, mainly in the introduction of teaching modes, and teaching skills in a flipped classroom, without any research on introducing flipped classroom into PE classes. The author is trying to apply the flipped classroom to the sports dance creation section, with introducing rich network learning resources to time limited classroom, to broadening the views of the students, stimulating students' interests, and developing students' autonomous learning consciousness, independent learning ability, and capacity of independent innovation [1-4].

\section{PROBLEMS EXISTING IN THE SPORTS DANCE TEACHING IN COLLEGES AND UNIVERSITIES}

Sports dance is a sports item that combines fitness, entertainment and, social contact, based on the form of double practice of men and women. In the actual situation, techniques and actions need to be reasonably linked based on the on-the-spot conditions, therefore, the creation rationality determines the action performance of both men and women. In this case, action creation is an important part in sports dance teaching. However, in terms of the sports dance elective

\footnotetext{
*Address correspondence to these authors at the Department of Physical Education, Northwest Agriculture and Forestry University, Yangling 7712100, Shaanxi, China; E-mail: ssdx_2015@sina.com
}

classes in colleges and universities, there are problems as follows:

\subsection{The Class Time Is Limited, Which Makes It Difficult to Ensure the Quality}

Due to limited class time, sports dance teaching mainly takes the form of lecture, with compression of the creation part, to improve the teaching efficiency. For example, there are 30 class hours for sports dance course in a semester, which is limited for covering all the contents, including teaching different dances, action creation, and examinations. Therefore, there are only 2 class hours for students to create new routine based on the basic elements learned in the traditional sports dance creation classes. Due to the limited time, the result is often not good, causing teachers omit the examination of this creation part. In this way, the sports dance creation is merely a form, without exercise, depending on the ability of students $[5,6]$.

\subsection{The Teaching Method Is Single, Lacking Innovation}

At present, the sports dance classroom teaching lacks innovation, with a single lecture and demonstration as the main method. Students are accepting the knowledge in a passive manner. They cannot actively participate in the teaching activity, with their learning initiative and mobilized creativity.

\subsection{The Examination Method of Sports Dancing Is One- Sided}

Sports dance is a sports item with a particular practicality. If it is examined in the traditional way in the final examination, with the content of the routine class, there is a great gap between students' scores and actual applications of sports dance [7].

Above all, we can see that the sports dance teaching is facing difficulties which need to be solved by a new teaching mode and methods to reform the sports dance teaching pro- 
cesses and examination methods. In order to exercise students' application ability and stimulate students' autonomous learning ability and innovation ability at the same time, the author, with the opportunity of sports dance course reform in our university, tried to divided the examination of sports dance into the following three steps: compulsory routine examination, creation action routine examination, and practical application of dance scene simulation examination. This paper studies the creation part of sports dance. With trying updated teaching ideas and taking flipped classroom as the breakthrough point, this paper solves the problem of limited class hours first; then repositions the roles of teachers and students and coordinates the relationship between teaching and learning, with students as the center of the teaching process; changes the examination contents, and guides students to the "examination driven and ability targeted" flipped classroom mode. In this way, the author hopes to stimulate learners' interest in learning, and improve autonomous learning and innovation ability, thereby improving the teaching effect $[8$, 9].

\section{DEVELOPMENT AND DESIGN OF FLIPPED CLASSROOM MODE FOR SPORTS DANCE CREA- TION CLASS}

At present, researches on practical level of flipped classroom is less than on theoretical level. This is because there are many unsolved issues, including thinking inertia of educators, adaptability of learners, complexity of the support environment, and effectiveness of in-depth study. Combining the advantages of flipped classroom, the author selectively applies it to sports dance teaching, starting from teaching target, with the guidance of specific tasks, to complete the teaching and examination of sports dance creation, and eventually to develop the innovation and practical ability of the students [10].

\subsection{Feasibility Analysis}

Sports dance creation class is generally arranged later in a semester, with the consideration that students will have the individual demands and desire of expression on the basis of mastering basic actions and accumulation of certain amount of material. By introducing the flipped classroom, problem of the limited time in sports dance class can be solved. On one hand, students can learn based on their interests and take steps in striking a balance between extracurricular activities and time; on the other hand, the class time can be best used for teaching.

\subsection{Overall Design Framework}

The core idea of flipped classroom is to flip the two links of obtaining and digesting the knowledge in traditional teaching activities. Outside the classroom, students conduct autonomous learning and inquiry learning, with being responsible for their own learning. During the class, the teacher is not the knowledge giver in the authoritative status, but the guide of learning activities and designer of teaching activities, i.e. teachers and students are equal to each other.

The flipped classroom mode should be focused on the teaching environment setting of before and during the class. Before class, teachers provide learning materials. Learning tasks and resources are given to students in advance. Students chose actions in different difficulty level to learn and create the prototype of the creation, based on their interests and abilities. During class, teachers explain the questions of the students and examine the learning situation of students.

\subsection{Design of Before Class Teaching Activities}

Teachers: Teachers refine the overall teaching goal of the sports dance course and define the sub goal of the sports dance creation part. Students are prepared with before class video materials which fits in the "theory of proximal development zone", stimulate the initiative of students, develop their potential, to obtain achievement experience from hard working.

Students: Students watch the whole video material based on the learning tasks given by teachers, discuss with their partners and determine new actions. Then they will combine the new actions with the mastered actions and create new routines.

Interaction between Teachers and Students: Teachers are not directly involved in their students' specific action learning and routine scheduling process, but to guide students to solve problems independently, such as the selection of learning material, the understanding of the problem tasks, and communication and practice situation of partners.

\subsection{Design of in Class Teaching Activities}

Teachers: Discuss the questions that cannot be solved by the students before the class, analyze the reasons and find the solution. Examine the task completion condition, mainly by self-assessment, mutual assessment among groups members, and comprehensive review $[11,12]$.

Students: Report the specific learning situation and progress and summarize the problems in the learning before class. Communicate and discuss with partners, based on the analysis and explanation of the teachers, to solve the problems with joints efforts.

Interaction between Teachers and Students: There are three aspects, including Q\&A of teachers, presentation of students, and comprehensive review, in the interaction during class. The whole process enables the interaction between teachers and students and among students, draw teachers and students together, embodies the student-center idea, and respects the demands of individuality expression.

\section{APPLICATION OF FLIPPED CLASSROOM TEACHING MODE BASED ON CREATION TASKS}

As a sports dance teacher, the author conducted teaching practice research on the sports dance creation part of the public required class (quick-quick-slow) for students in 2014 study year in Northwest Agriculture and Forestry University of Science, with focus on the positive effect of flipped classroom in the teaching practice. Based on the Robert Talbert research, the author designed two stages including before class autonomous learning and in class digestion to implement the flipped classroom mode, combined with the features of sports dance course and college students' learning characteristics (as shown in Fig. 1). 


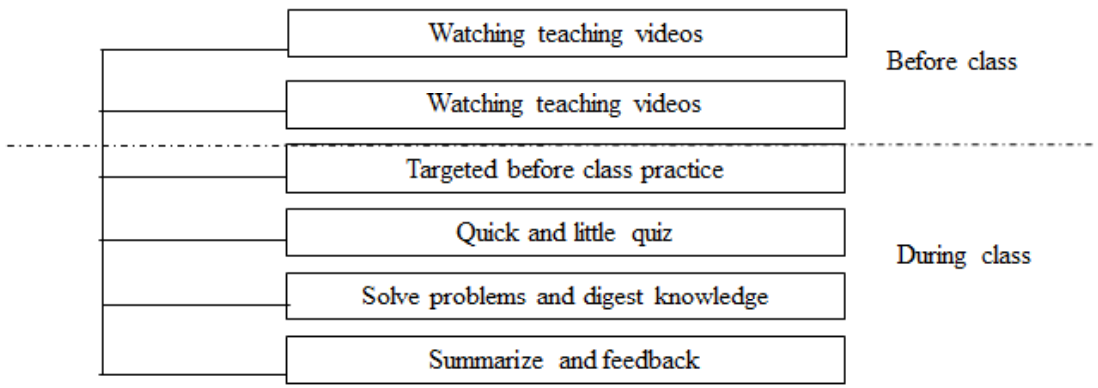

Fig. (1). Flipped classroom diagram by Robert Talbert.

\subsection{Subject $E$}

Subject: Students of 2014 study year who selected the class of sports dance in Northwest Agriculture and Forestry University of Science.

Purpose: Students are required to self-study one or two new actions and create actions with those newly learnt actions and mastered actions. Since it is self-studied by students, the actions should not be too much. In this way, students can independently complete the task and obtain self achievement after hard working. Otherwise, students will feel frustrated on one hand, and on the other, they may focus on learning new actions, rather than the creation of their own actions. This study has been conducted to check if flipped classroom mode can stimulate learners' interests, improve learners' autonomous learning ability and innovation ability, and improve the teaching effect.

\subsection{Before Class Learning Design}

\subsubsection{Appropriate Video Material Is the Foundation of Teaching}

"Flipped classroom" is based on appropriate teaching video materials. The video materials used in this study is a series of videos recorded by all the teachers in the first domestic training class of sports dance teachers (referees), which are the most authoritative, detailed, and regulated teaching video materials around the country. Related videos can be searched by the keywords of "fitness dancing teaching" and "quick-quick-slow". There are two levels of "quickquick-slow" videos: basic and advanced composition. Students can choose based on their own abilities.

\subsubsection{Before Class, Practice Is the Premise}

By practicing before class, students can preliminarily understand the actions and accumulate resources for dance creation; and find the disadvantage part to discuss with teachers during the class. Learning with the purpose of solving problems could better mobilize the initiative of students and improve teaching efficiency.

\subsection{In Class Learning Design}

4.3.1. The Principle of Students' Exploration First and Teachers' Guidance Second Is the Key to Implement Flipped Classroom

The independent exploration stage is the essential link for students to master, use, digest, and develop knowledge. Dur- ing the flipped classroom teaching, teachers should observe more, with patience and care. The attention of teachers is the encouragement to students. Teachers should believe that students can grow by their own hard work. Do not interrupt their independent exploration and allow students to establish their own knowledge system during independent learning.

4.3.2. Discussion and Research Between Teachers and Students Is the Powerful Guarantee to Smooth Implementation of Flipped Classroom

Teachers should pay attention to students' learning progress at any time and analyze together with students and solve the problems when students are facing some difficulties. For example: when facing technical problems in new actions, teachers can inspire and guide students to find the key point and difficult point in that. Based on the explanation and demonstration of teachers, students should simulate and practice until they master the actions. If it is a layout problem, teachers can provide multiple cohesive skills for reference to inspire the students and choose based on their own needs.

\subsubsection{Results Display and Communication Is the Catalyst to Improve the Flipped Classroom Effect}

Result display can provide a show platform for the students, and meet the needs of communication at the same time. By result display, students can be encouraged to better learn the knowledge of sports dance, improve their skills, with better appreciation value. In addition, the display contents are not constrained in the classroom, which in turn will widen students' sight, stimulate their innovation ability, and realize the cultivation of creative thinking, see Table 1.

\subsubsection{Timely and Accurate Assessment and Feedback Is the Promoter of Flipped Classroom Effect}

The assessment of flipped classroom mode is open, multi-dimensional, and multi-mode, included with assessment from teachers, students themselves, partners, and classmates. The contents include completion of creation task, questions raised by students, independent thinking and problem solving, and result display.

\subsection{Analysis of the Effect of Flipped Classroom Teaching}

Taking creation tasks as the breakthrough points, the experimental teaching of flipped classroom mode in sports dance has achieved a significant experimental result. The author carries on a questionnaire survey of students after the 
Table 1. Assessment of students to the application of flipped classroom teaching mode.

\begin{tabular}{|c|c|c|c|}
\hline & Agree & Don't know & Don't Agree \\
\hline \hline Teaching methods satisfaction & $229(97 \%)$ & $7(3 \%)$ & 0 \\
\hline Application timing & $212(89.8 \%)$ & $24(10.2 \%)$. & 0 \\
\hline class hour & $180(76.3 \%)$ & $10(4.2 \%)$ & $46(19.5 \%)$ \\
\hline
\end{tabular}

Table 2. Satisfaction of students of the learning results.

\begin{tabular}{|c|c|c|c|c|}
\hline & Very & Yes & Uncertain & No \\
\hline \hline Improves learning interest & $216(91.5 \%)$ & $15(6.4 \%)$ & $9(2.1 \%)$ & $3(1.3 \%)$ \\
\hline $\begin{array}{c}\text { Exercises ability of auton- } \\
\text { omous learning }\end{array}$ & $191(80.9 \%)$ & $33(14 \%)$ & 0 & 0 \\
\hline Improves creation ability & $210(89 \%)$ & $26(11 \%)$ & 0 & 0 \\
\hline Widens sight & $224(81.3 \%)$ & $2(12.2 \%)$ & & 0 \\
\hline
\end{tabular}

experiment, to deeply understand and evaluate the satisfaction of students for the flipped classroom mode. Teaching mode application mainly includes satisfaction degree to the teaching manner, timing of the application, and rationality of the class hour arrangement. Satisfaction with learning results mainly includes: simulation of learning interest, change of learning attitude, and improvement in learning ability. Through the questionnaire survey of 236 freshmen in 6 sports dance classes of 2014 study year, the results show: Students generally recognize the implementation of the teaching mode and are satisfied with their own knowledge and ability improvement, see Table $\mathbf{2 . 7 6 . 3 \%}$ students think that a 2-hour class for flipped classroom is not enough and suggested a 4-hour class instead. $2.1 \%$ students think that flipped classroom cannot improve their learning interests; $1.3 \%$ students think that flipped classroom does not help in improving autonomous learning ability. This may be because they are not interested in sports dance and have to choose sports dance course due to limited courses.

\section{PROBLEMS AND PROSPECT}

\subsection{Problems}

Overall, the effect of design of flipped classroom with dance creation as the breakthrough point is significant. But there are still some problems: First, the class hour is not enough. On one hand, some commonly used skills for dance creation need some time to teach. On the other hand, students need some time to digest and consolidate the newly learnt actions and creation routines. Second, it raises higher requirements for the teachers' knowledge, skills, and teaching ability. During class in flipped classroom mode, teachers should be proficient in the contents to quickly respond and find the key point when students are facing some problems and asking for help.

\subsection{Prospects of Applying Flipped Classroom}

\subsubsection{It is an Art to Choose the Timing of Flipped Class- room Teaching Mode}

Teachers should decide to use traditional teaching mode or flipped classroom mode based on the content to teach. In terms of sports dance course, not every class needs flipped classroom. For example, sports dance movement position and sense, and action requirements will make it difficult for beginners to accept a flipped classroom. However, in later period of the semester, when students need new information and knowledge, the application of flipped classroom could further simulate the curiosity and inspire students' thinking.

\subsubsection{The Successful Application of Flipped Classroom Is Associated With the Update of Education Ideas}

The multi-dimensional evaluating makes flipped classroom not only focus on students' learning efficiency and grades, but also find the meaning of independent learning process to the development of students.

\subsubsection{Flipped Classroom Is About Teaching Form, and More About Teaching Thinking}

Introducing the rich network resources to limited classroom teaching, can widen students' sight and increase students' knowledge range. All the resources provided on the Internet in multiple forms and rich contents can overcome the influence of geography and economy, to better share the achievements of human civilization.

\subsubsection{Flipped Classroom Brings More Challenge and Mo- tivation for the Teaching of The Teachers}

Teachers' classroom teaching is no longer the relatively closed environment; it is an open dynamic interaction process, in which, teachers should pay attention to the improvement of comprehensive quality to better meet the needs of teaching.

\section{CONFLICT OF INTEREST}

The author confirms that this article content has no conflict of interest.

\section{ACKNOWLEDGEMENTS}

This work is supported by the Project of Research on teaching reform of North West Agriculture and Forestry University (Item number: JY1302139). 


\section{REFERENCES}

[1] X. Zhang, and W. He, "Research on Network Teaching System Model with Flipped Classroom," Modern Education Technology, no. 8 , pp. $21-25,2013$.

[2] H. Li, "Flipped Classroom Mode Design and Application Based on Tasks," Modern Education Technology, no. 9, pp. 46-51, 2013.

[3] Y. Cao, "Innovative Application of Flipped Classroom in Software Technology Training," China Audio-visual Education, no. 4, pp. 116-120, 2014.

[4] L. Dong, "Jiao Baocong. Research on Teaching Application Model based on Flipped Classroom Concept," Audio-visual Education Research, no. 7, pp. 108-113, 2014.

[5] Q. Lin, "Modern Education Technology" Experimental Curriculum Design Based on Flipped Classroom," Laboratory Research and Exploration, no. 1, pp. 173-176, 2014.

[6] X. Zhang, "Flipped Classroom Based on QQ group and Tablet PC," Audio-visual Education Research, no. 8, pp. 68-72, 2013.
[7] Q. Zhang, and A. Wang, "New Hybrid Teaching Mode Based on Flipped Classroom," Modern Education Technology, no. 4, pp. 2732,2014

[8] H. Wang, and Z. Li, "Application of Flipped Classroom in English Teaching," Teaching and Management, no. 7, pp. 141-144, 2014.

[9] H. Wang, "The design of Flipped Classroom mode Based on Typical Domestic and Foreign Cases," Modern Education Technology, no. 8, pp. 5-10, 2013.

[10] H. Zhu, and Y. Zhu, "On Flipped Classroom and Its Effective Implementation," Audio-visual Education Research, no. 8, pp. 7983, 2013.

[11] R. Talbert, "Inverting the Linear Algebra Classroom [DB/OL]," http://prezi.com/dz0rbkpy6tam/inverting-the-linear-algebraclasssroom, 2013.

[12] S. C. Kong, "Developing information literacy and critical thinking skills through domain knowledge learning in digital classrooms: An experience of practicing flipped classroom strategy," Computers \& Education, vol. 78, 2014.

Received: June 10, 2015

(C) Yonghua Li; Licensee Bentham Open.

This is an open access article licensed under the terms of the (https://creativecommons.org/licenses/by/4.0/legalcode), which permits unrestricted, noncommercial use, distribution and reproduction in any medium, provided the work is properly cited. 